\title{
CAMBRIDGE
}

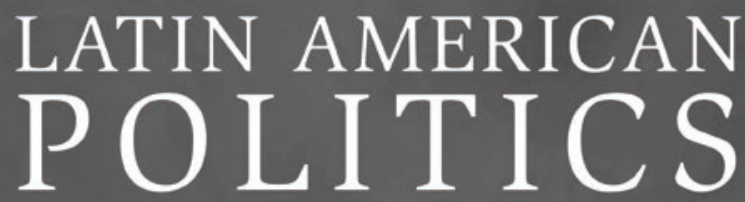

FROM CAMBRIDGE
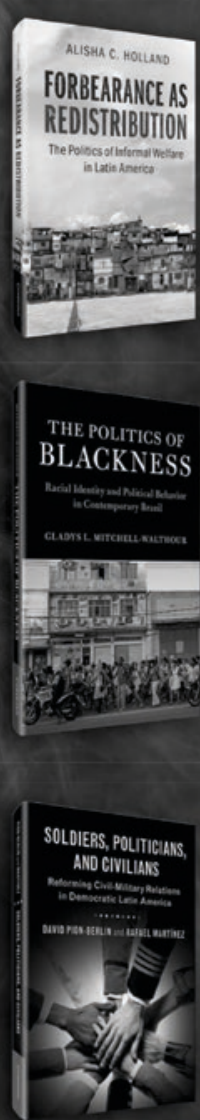

FORBEARANCE AS REDISTRIBUTION

The Politics of Informal

Welfare in Latin America

Alisha C. Holland

Part of Cambridge Studies in Comparative Politics

ISBN 9781316626351

\section{THE POLITICS OF} \section{BLACKNESS}

Racial Identity and Political Behavior in Contemporary Brazil

Gladys L. Mitchell-

Walthour

Part of Cambridge Studies in Stratification Economics: Economics and Social Identity

ISBN 9781316637043

SOLDIERS, POLITICIANS, AND CIVILIANS

Reforming Civil-Military Relations in Democratic Latin America

David Pion-Berlin and Rafael Martínez

ISBN 9781316604434
MAKING PEACE

IN DRUG WARS

INDRUG WARS

Crackdowns and Cartels in Latin America

Benjamin Lessing

Part of Cambridge

Studies in Comparative Politics

ISBN 9781316648964

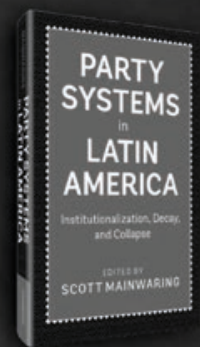

PARTY SYSTEMS

IN LATIN

AMERICA

Institutionalization,

Decay, and Collapse

Edited by Scott

Mainwaring

ISBN 9781316627525
View these titles and more at www.cambridge.org/LatAmPoli
CAMBRIDGE UNIVERSITY PRESS 


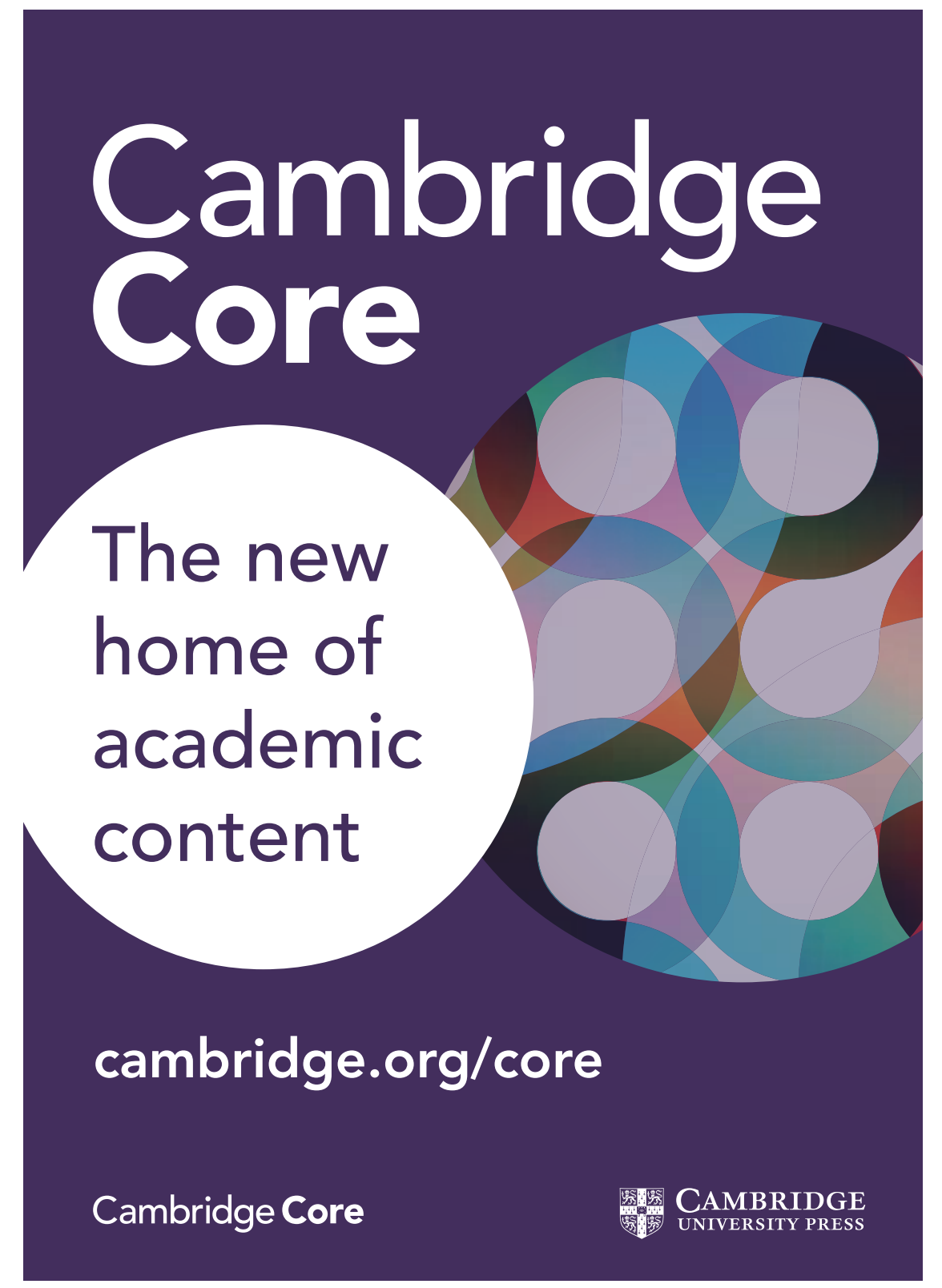




\section{Cambridge Journals Digital Archive}

Knowledge is no longer shelved
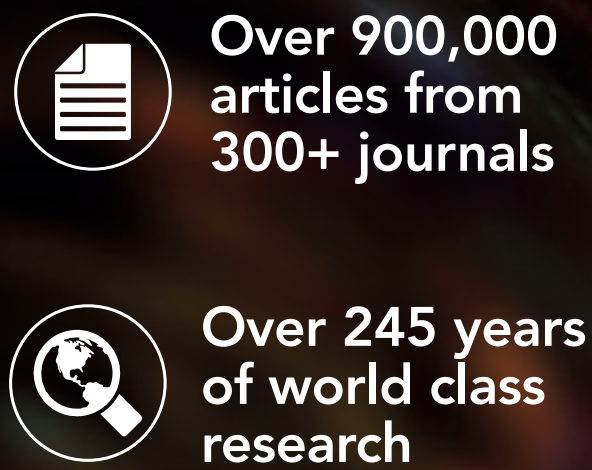

Available in collections, bespoke packages and as individual journal archives

cambridge.org/core-cjda 


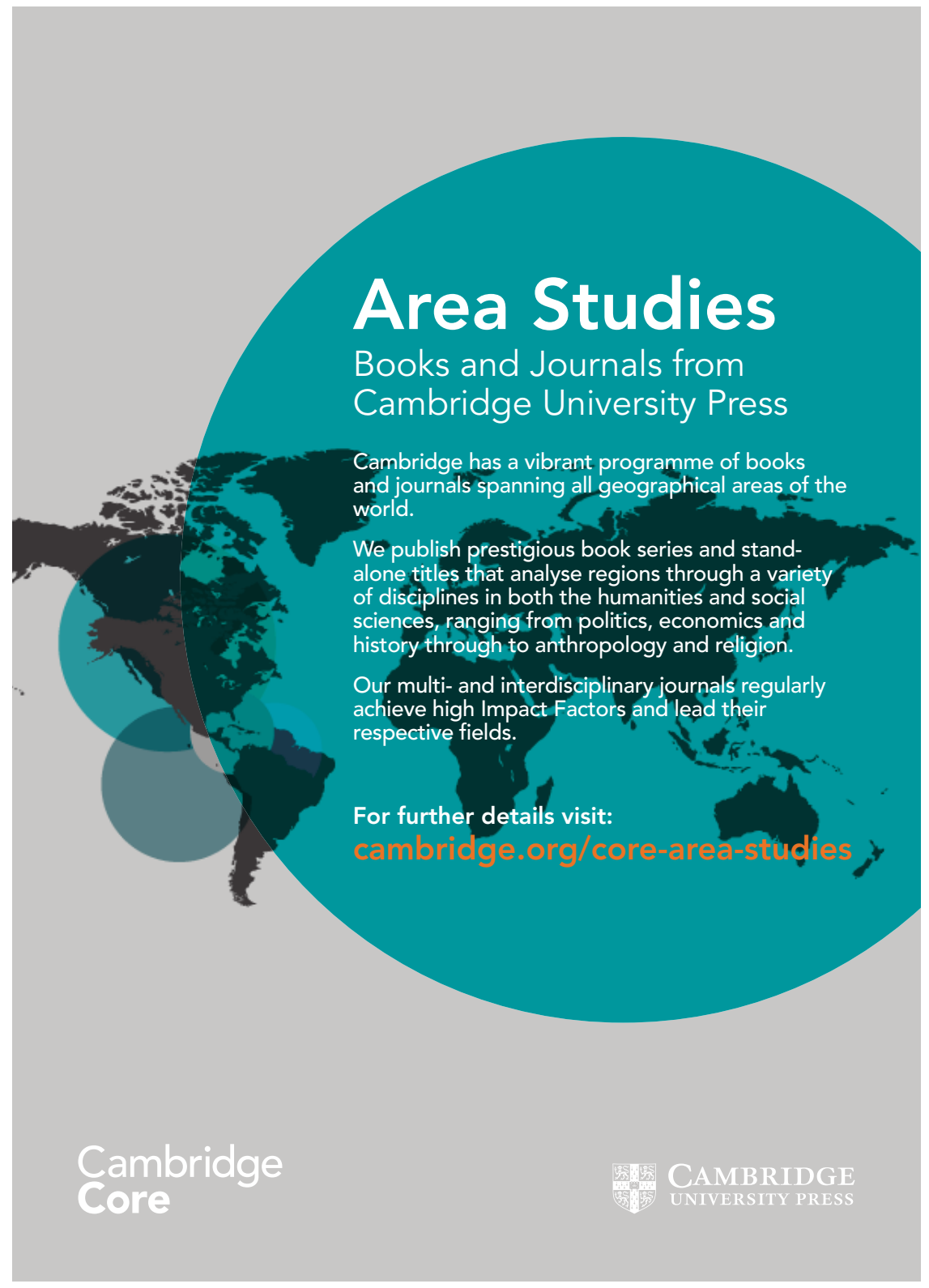




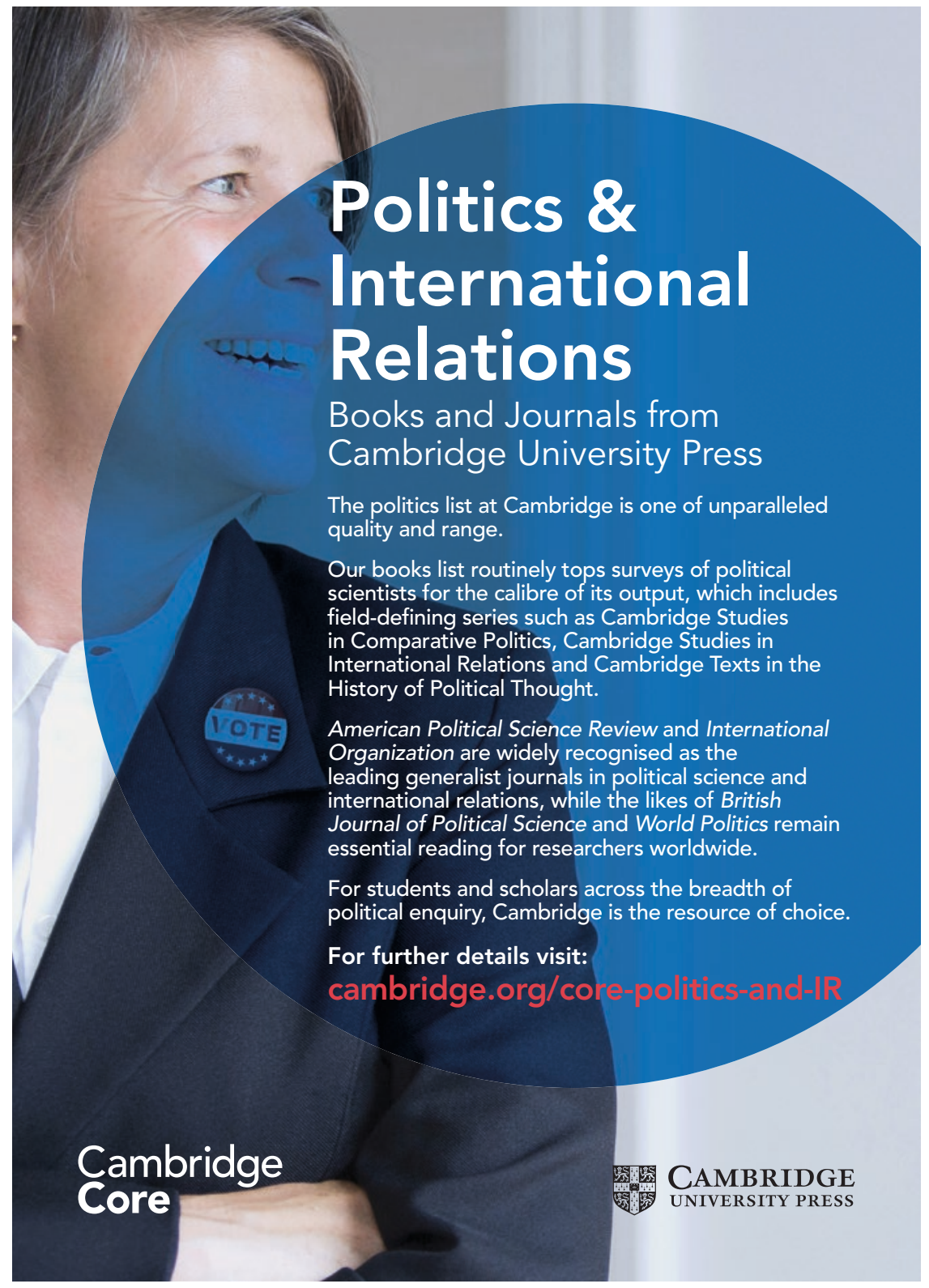


Latin American Politics and Society (formerly the Journal of Interamerican Studies and World Affairs) publishes the highest-quality original social science scholarship on Latin America. The Editorial Board, comprising leading U.S., Latin American, and European scholars, is dedicated to challenging prevailing orthodoxies and promoting innovative theoretical and methodological perspectives on the states, societies, economies, and international relations of the Americas in a globalizing world. www.cambridge.org/LAPS

SUBSCRIPTION INFORMATION Latin American Politics and Society is published quarterly (February, May, August, and November) by Cambridge University Press, One Liberty Plaza, New York, NY 10006, USA.

The subscription price of Volume 62 (2020), including delivery by air where appropriate (but excluding VAT), is $\$ 936$ ( $£ 668$ ) for institutions print and online; US\$780 (GB£557) for institutions online only. An individual print and online subscription is US\$75 (GB£57). Single copy price: US\$40 (£30).

Orders, which must be accompanied by payment, may be sent to a bookseller, subscription agent, or direct to the publisher: Cambridge University Press, Journals Fulfillment Department, One Liberty Plaza, New York, NY, 10006, USA; or Cambridge University Press, UPH, Shaftesbury Road, Cambridge CB2 8RU, England. For single issues, please contact subscriptions_newyork@cambridge.org.

ADVERTISING For information on display ad sizes, rates, and deadlines for copy, please contact USAdSales@cambridge.org.

\section{ISSN: 1531-426X EISSN: 1548-2456}

(C) 2020 University of Miami. All rights reserved. No part of this publication may be reproduced, in any form or by any means, electronic, photocopying, or otherwise, without permission in writing from Cambridge University Press. Policies, request forms and contacts are available at: http://www.cambridge.org/about-us/rights-permissions. Permission to copy (for users in the U.S.A.) is available from Copyright Clearance Center http://www.copyright.com, email: info@copyright.com.

POSTMASTER Send address changes to Latin American Politics and Society, Cambridge University Press, One Liberty Plaza, New York, NY 10006, USA.

ABSTRACTED AND INDEXED IN Hispanic American Periodicals Index, Historical Abstracts, International Political Science Abstracts, Peace Research Abstracts, Public Affairs Information Service, Current Contents, Social Sciences Citation Index, Social Sciences Index, ABC POL SCI, Academic Search Premier, and United States Political Science Documents. Available in full text online through Cambridge University Press. Back issues available through ProQuest and JSTOR. Content for volumes 46-49 (2004-2007) available through Project MUSE®.

INSTRUCTIONS FOR CONTRIBUTORS Can be found at www.cambridge.org/LAPS-IFC

EDITORIAL CORRESPONDENCE Latin American Politics and Society, University of Miami, PO Box 248282, Coral Gables, Fl 33124-2237, USA. Telephone (305) 284-5554. LAPS.sis@miami.edu.

BOOKS FOR REVIEW AND BOOK REVIEW CORRESPONDENCE Dr. Alfred Montero, Book Review Editor, Department of Political Science, Carleton College, One North College Street, Northfield, MN 55057-4025. amontero@carleton.edu 


\title{
Latin American Politics And Society
}

\author{
Vol. 62, No. 3 Fall 2020
}

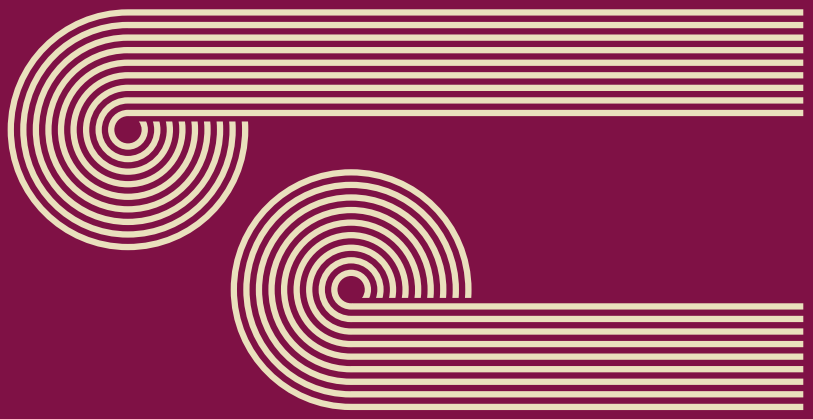

Cambridge Core

For further information about this journal please go to the journal website at: cambridge.org/laps
CAMBRIDGE

UNIVERSITY PRESS 